\title{
Challenges in pulmonary fibrosis 2 : Bronchiolocentric fibrosis
}

\author{
Jean-François Cordier
}

Bronchiolocentric fibrosis is essentially represented by the pathological pattern of constrictive fibrotic bronchiolitis obliterans. The corresponding clinical condition (obliterative bronchiolitis) is characterised by dyspnoea, airflow obstruction at lung function testing and air trapping with characteristic mosaic features on expiratory high resolution $C T$ scans. Bronchiolitis obliterans may result from many causes including acute diffuse bronchiolar damage after inhalation of toxic gases or fumes, alloimmune chronic processes after lung or haematopoietic stem cell transplantation, or connective tissue disease (especially rheumatoid arthritis). Airway-centred interstitial fibrosis and bronchiolar metaplasia are other features of bronchiolocentric fibrosis.

Correspondence to: Professor JeanFrançois Cordier, Claude Bernard University and Department of Respiratory Medicine, Reference Center for Orphan Pulmonary Diseases, Louis Prade University Hospital, 69677 Lyon (Bron), France; jean-francois.cordier@ chu-lyon.fr

Received 30 January 2006 Accepted 18 July 2006
$\mathrm{P}$ ulmonary fibrosis is usually taken to mean interstitial alveolar fibrosis as best illustrated by the pathological pattern of usual interstitial pneumonia defining idiopathic pulmonary fibrosis. However, fibrosis may affect any part of the lung, especially the bronchioles and the surrounding alveolar structures, with possibly severe functional consequences.

The bronchioles represent a transitional area between the bronchi and the alveoli. When submitted to acute or chronic injury, the large bronchi may dilate but almost never get fibrosed, whereas the small airways either undergo fibrosing bronchiolitis, reducing their calibre, or are almost destroyed with ensuing dilatation and centrilobular emphysema. Because the bronchioles are surrounded by alveoli in the lobule and are also in continuity with the respiratory bronchioles, the alveolar ducts and the alveoli, the inflammatory and fibrosing bronchiolar processes may extend to the peribronchiolar interstitium. Bronchiolocentric fibrosis may therefore involve both the bronchiole itself and the peribronchiolar interstitium.

Although the pathology is the key to the classification of the bronchiolocentric fibrosing processes, the final diagnosis requires a balanced combination of clinical, pathological, functional and imaging features.

\section{BRONCHIOLITIS OBLITERANS}

The terminology of bronchiolitis obliterans has been a source of confusion which has not yet been completely resolved. It was first used by pathologists and then by clinicians to name several clinical-pathological syndromes that are quite
Thorax 2007;62:638-649. doi: 10.1136/thx.2004.031005

distinct except for the common semantic denominator of bronchiolitis obliterans.

Constrictive bronchiolitis obliterans is an uncommon and usually purely bronchiolar lesion characterised by mural fibrosis resulting in concentric reduction in the calibre of the bronchiole (fig 1), possibly with complete scarring and fibrous obliteration of the airway. It was macroscopically identified by Reynaud ${ }^{1}$ who studied obliteration of the bronchi and reported that he could discern a fibrous cord tracing the initial course of the obliterated small bronchi. Lange ${ }^{2}$ described bronchiolitis obliterans microscopically in patients dying from infectious pulmonary disease, and Fraenkel $^{3}$ reported bronchiolitis obliterans in a patient who died after inhalation of nitric acid fumes, with precise histopathological illustrations of bronchiolitis obliterans in both papers. Since then many papers have described this entity in various aetiological settings. This rare condition has become widely known, especially since it appears as a prejudicial complication of lung and haematopoietic stem cell (HSC) transplantation. ${ }^{4-12}$ In this review the term "bronchiolitis obliterans" will be used to designate pathologically defined constrictive bronchiolitis obliterans unless otherwise specified. Diffuse bronchiolitis obliterans results in airflow obstruction at lung function testing.

The term "obliterative bronchiolitis" (often considered as synonymous with bronchiolitis obliterans) will be used specifically for the clinical syndrome associating airflow obstruction and high resolution CT (HRCT) features of small airways disease occurring generally within a specific setting, with or without pathological confirmation of bronchiolitis obliterans. In patients followed after lung transplantation for early detection of post-transplant airflow obstruction, the term "bronchiolitis obliterans syndrome (BOS)" is used when airflow obstruction is detected by lung function testing without the need for pathological proof of bronchiolitis obliterans. This terminology has not yet been adopted outside the field of lung transplantation. Obliterative bronchiolitis may

\footnotetext{
Abbreviations: BOOP, bronchiolitis obliterans with organising pneumonia; $\mathrm{BOS}$, bronchiolitis obliterans syndrome; COPD, chronic obstructive pulmonary disease; $\mathrm{FEF}_{25-75}$, mid expiratory flow rate between $25 \%$ and $75 \%$ of FVC; $F E V_{1}$, forced expiratory volume in $1 \mathrm{~s}$; FVC, forced vital capacity; GVHD, graft-versus-host disease; HLA, human leucocyte antigen; HRCT, high resolution computed tomography; HSC, haematopoietic stem cell; RV, residual volume; TLC, total lung capacity; TNF, tumour necrosis factor
} 


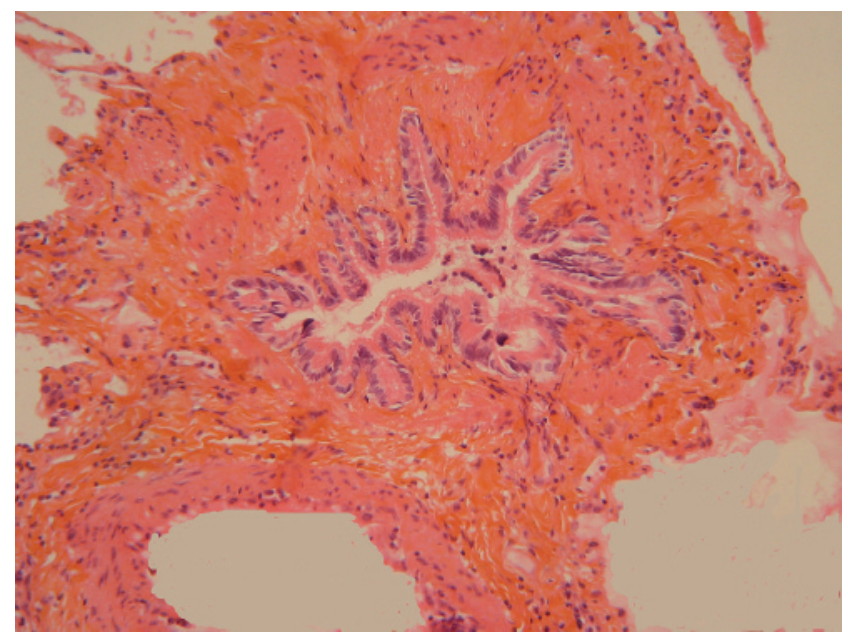

Figure 1 Constrictive bronchiolitis with fibrosis of the bronchiolar wall in a patient after haematopoietic stem cell transplantation.

occasionally correspond to inflammatory bronchiolitis without fibrosis (improvement may occur with corticosteroid treatment).

The other pathological type of bronchiolitis obliterans is characterised by intraluminal buds (polyps) of granulation tissue inside the lumen of the bronchiole without significant mural bronchiolar fibrosis (this pathological pattern has also been called "proliferative bronchiolitis"). The polyps adhere to the bronchiole on a part of its circumference where the epithelium is destroyed (whereas it is usually preserved over the rest of the circumference). These polyps are usually in continuation with polyps within the lumen of the distal air spaces (especially the alveoli). In most cases the major lesion is represented by the polyps in the distal air spaces and is called "organising pneumonia". Proliferative bronchiolitis obliterans is just an accessory finding, and this is why the term "bronchiolitis obliterans with organising pneumonia (BOOP)" has been abandoned in the American Thoracic Society/ European Respiratory Society International Multidisciplinary Consensus Classification of the Idiopathic Interstitial Pneumonias $^{13}$ in favour of organising pneumonia (cryptogenic organising pneumonia when no cause is found).

Bronchiolitis obliterans may be a chronic process or the consequence of severe acute bronchiolar damage. Chronic severe bronchiolitis may evolve to end-stage bronchiolitis associating constrictive bronchiolar fibrosis, bronchiolectasis with mucostasis, inflammation and further infectious complications.

\section{PATHOGENESIS OF BRONCHIOLAR AND PERIBRONCHIOLAR FIBROSIS}

The pathogenesis of fibrosis is a complex interplay between inflammatory and mesenchymal cells and the many components of the extracellular matrix. It is orchestrated by structural resident cells of the lung-inflammatory and immune cells and mesenchymal cells (fibroblasts and myofibroblasts)—which are the final producers of components of the extracellular matrix constituting fibrosis. Mediators of inflammation and angiogenesis, proteins of the coagulation and fibrinolysis cascades, cytokines and matrix metalloproteinases are the main agents operating in the building and remodelling of fibrosis. Fibrosis may consist of granulation tissue with loose connective matrix organisation (as in wound healing) or of scarring with dense connective matrix organisation. Whereas the former is often reversible (especially with corticosteroid treatment), the latter (which consists of compact bundles of collagen, mainly collagen I) is irreversible.

From the point of view of the clinical histopathological physiology, three different principal processes account for bronchiolar fibrogenesis: (1) inflammatory bronchiolar injury with reversible fibrosis; (2) acute or subacute chronic inflammatory bronchiolar injury with irreversible fibrosis; and (3) chronic irreversible bronchiolar fibrosis. ${ }^{7} 1415$

Acute inflammatory bronchiolar injury in infectious disease was meticulously studied by McLean ${ }^{15}$ on nearly 20000 serial sections from selected blocks of lung tissue from 70 patients which allowed him to distinguish two phases: exudative and repair. The first phase is characterised by the destruction of surface epithelium with occlusion of the bronchiole by cellular debris and fibrinous exudates. Depending on the cause of the infectious process (viral or bacterial, or viral with secondary bacterial infection), mononuclear or polymorphonuclear mural inflammation occurs. The regeneration of the epithelium starts from the preserved basement membrane. However, in some cases, severe ulceration of the epithelium and injury to the underlying basement membrane, subepithelial connective matrix and smooth muscle cells result in irreversible damage. Bronchiolar obliteration is the consequence of both the organisation of fibrinous exudates within the bronchiolar lumen and bronchiolar collapse. The organising process is characterised by fibroblasts and capillaries invading the lumen at sites where the original epithelium is no longer present. The material thus organised forms a granulation tissue similar to cutaneous wound healing with some well individualised plugs of granulation tissue comparable to the intra-alveolar plugs found in cryptogenic organising pneumonia. When the whole epithelium is destroyed together with the basal lamina and the subepithelial layer (ulcerative bronchiolitis) and further bronchiolar collapse occurs, adequate repair is not possible and fibrous obliteration of the bronchiole is irreversible. The connective tissue cords of such scars have the appearance of periarterial fibrosis and often make the bronchioles difficult to detect. The bronchiolar epithelium frequently colonises the air spaces about which this scar terminates. ${ }^{14}$

Inhalation of toxic fumes or gases is another cause of bronchiolitis obliterans with a temporally defined injury, as in silo filler's disease secondary to inhalation of high concentrations of nitrogen oxides. ${ }^{16}{ }^{17}$ The pathological lesions in fatal cases consist of diffuse bronchiolar damage with multiple bronchiolocentric miliary nodules corresponding to bronchiolitis obliterans with severe injury to the bronchiolar wall which is destroyed over a large portion of its circumference and replaced by plugs of fibrin, inflammatory cells and fibroblasts. The most severely damaged bronchioles are recognisable only by remnants of their muscular coat. ${ }^{18}$ In severe cases, injury with intraluminal plugs may extend to the contiguous alveolar ducts and alveoli. ${ }^{19}$ In contrast, in less severe cases with wellindividualised plugs within the bronchiolar lumen ("organising bronchiolitis"), the evolution is favourable (with possible development of mild centrilobular emphysema). ${ }^{20}$ Similar findings have been reported in other cases of inhalational injury with nitric oxide. ${ }^{192122}$

An experimental model using intratracheal injection of a dilute solution of nitric acid in rabbits produced bronchiolitis obliterans. ${ }^{23}$ The pathogenesis of the lesions was traced, with the first demonstrable change being haemorrhage from the capillaries of the respiratory bronchioles. This was followed by necrosis and desquamation of the bronchiolar epithelium with formation of "coagulum-filled epithelium-covered papillary processes", then fibroblastic activity and definite scar tissue after 2 weeks. In this model, cortisone prevented the development of bronchiolitis obliterans. A similar model in rats showed 

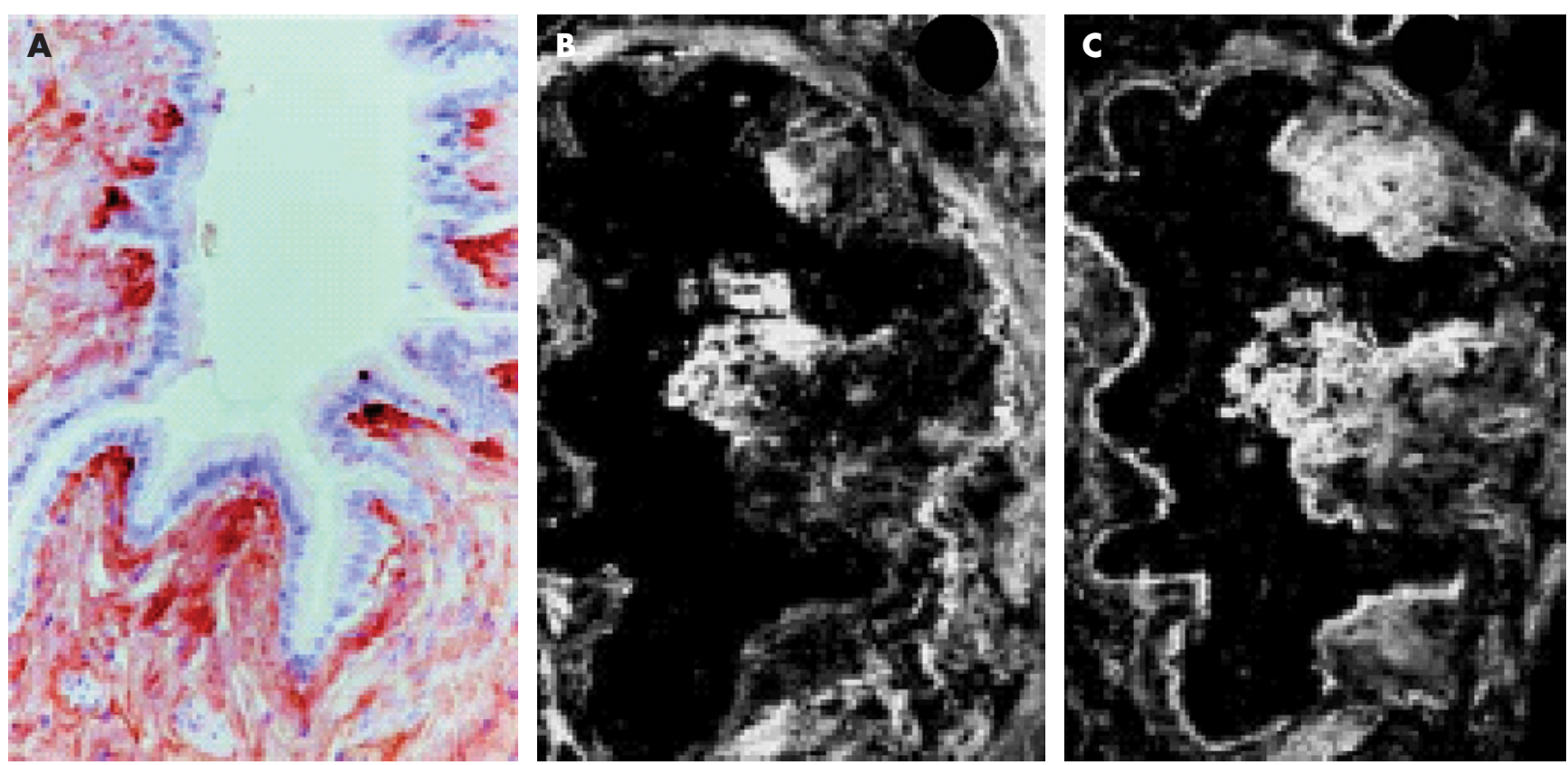

Figure 2 Fibrogenesis of bronchiolitis obliterans (fibro-inflammatory stage) after bone marrow transplantation. Fibrillar deposits of connective matrix in intraluminal protrusion with (A) anti-lysil oxidase staining (indirect immunoperoxidase method, (B) anti-tenascin and (C) anti-plasmatic fibronectin labelling (indirect immunofluorescence method). Reproduced from Streichenberger et a ${ }^{26}$ with kind permission of Springer Science and Business Media.

an early stage characterised mainly by proliferative bronchiolitis obliterans followed by constrictive bronchiolitis obliterans, areas of complete bronchiolar destruction and bronchiolar epithelial cell hyperplasia around the fibrotic areas, extending into the surrounding acini. ${ }^{24}$

Bronchiolitis obliterans with chronic irreversible fibrosis may be associated with inflammatory and/or immune processes as seen in rheumatoid arthritis or in graft-versus-host disease (GVHD) after HSC transplantation or after lung transplantation. The inflammatory process is mainly subepithelial and mural (with the epithelium usually preserved). GVHD after HSC transplantation may affect the airways throughout their length, with the bronchi developing lymphocytic bronchiolitis and eventually bronchiectasis ${ }^{25}$ and the small airways being injured by lymphocytic cellular bronchiolitis and eventually bronchiolitis obliterans in a number of patients. ${ }^{45}$

Fibrogenesis of bronchiolitis obliterans after HSC transplantation has been studied comparatively in two patients, one with fatal obliterative bronchiolitis and the other with a good outcome. ${ }^{26}$ Both patients had previously developed GVHD with severe skin manifestations. In both patients the fibrosing process affected all the terminal bronchioles without conspicuous involvement of the alveolar duct region. The early inflammatory stage was characterised by subepithelial bronchiolar inflammatory cell clusters, mostly lymphocytes with CD8+ subtypes predominating over CD4+ cells. The fibro-inflammatory stage combined a persistent immune cellular lesion pattern with focal modelling of a subepithelial neo-synthesised connective matrix. Expression of lysyl-oxidase (an enzyme with a unique role in collagen cross-linking protecting the extracellular matrix against degradation by metalloproteinases) was observed at the tips of the intraluminal fibrotic protrusions together with tenascin and cellular fibronectin (fig 2). The later fibrotic stage was characterised by dense extracellular matrix deposits spreading throughout the peribronchiolar connective tissue with persistence of lysyl-oxidase expression, resulting in obliteration and finally disappearance of the bronchioles. While the inflammatory and fibro-inflammatory stages of bronchiolitis obliterans were present in both patients, the fibrotic stage was present only in the patient with severe advanced disease leading to death. This suggests that only the first two stages undergo stabilisation (with increased corticosteroid treatment and immunosuppression), whereas the fibrotic stage with persistence of lysyl-oxidase expression results in irreversible chronic obstructive lung disease (COPD).

Bronchiolitis obliterans may occasionally be diagnosed without evident inflammation. In such cases it is not possible to determine whether a previous inflammatory process abated or whether idiopathic "fibroproliferation" occurred (as in usual interstitial pneumonia). Inflammatory bronchiolar injury with reversible fibrosis is characteristically seen in bronchiolitis obliterans associated with cryptogenic organising pneumonia. In such cases, fibrosis consists of granulation tissue similar to that of wound healing with a loose connective matrix characteristic of the reversible type of fibrosis. ${ }^{27}$ This pattern of intraluminal bronchiolar organisation, which is found in $75 \%$ of patients with chronic organising pneumonia of unknown cause, is also present in hypersensitivity pneumonitis in about $25 \%$ of cases, but only rarely in the other interstitial lung disorders including usual interstitial pneumonia, pulmonary sarcoidosis and Langerhans' cell granulomatosis. ${ }^{28}$ Proliferative bronchiolitis obliterans and organising pneumonia may represent similar patterns of response to injury in the bronchioles and alveoli, respectively. ${ }^{27-29}$

The origin of the fibroblasts involved in the processes of bronchiolar fibrosis is not established. In pulmonary fibrosis they may arise from local airway fibroblasts or from bone marrow-derived progenitor cells. ${ }^{30} 31$ Analysis of in situ microchimerism and sex chromosomes (in cases with appropriate sex mismatch) of fibroblasts present in bronchiolitis obliterans in human lung transplants demonstrated the involvement of circulating fibroblastic precursor cells, most probably derived from bone marrow. These were recipient-derived fibroblasts in patients who underwent lung transplantation followed by bronchiolitis obliterans, and donor-derived fibroblasts in two additional patients who developed bronchiolitis obliterans after HSC transplantation. ${ }^{32}$ 


\section{OBLITERATIVE BRONCHIOLITIS SYNDROME}

Fibrosing constrictive bronchiolitis obliterans results in a characteristic obliterative bronchiolitis syndrome allowing confident establishment of a diagnosis without pathological confirmation in most cases when it presents in a characteristic context.

\section{Clinical manifestations}

Dyspnoea is the main symptom, but it usually manifests only once airflow obstruction is advanced. Chronic cough may be present. In advanced disease, bronchorrhoea and iterative bronchial infection are the consequences of bronchial dilation most often associated with bronchiolar disease. Pulmonary examination may reveal signs of hyperinflation. At auscultation, mid-inspiratory squeaks are characteristic. Some wheezes and crackles may be present.

\section{Functional characteristics}

The diffuse reduction of the calibre of the small airways results in non-reversible airflow obstruction. However, when the bronchioles are completely occluded, the air flow is suppressed (even if some ventilation persists through the collateral ventilation from less affected adjacent areas). Furthermore, peribronchiolar fibrosis of the interstitium may contribute to some restriction.

Airflow obstruction is usually defined by a ratio of forced expiratory volume in $1 \mathrm{~s}\left(\mathrm{FEV}_{1}\right)$ to forced vital capacity (FVC) of $\leqslant 0.7$ which is not reversible, as proposed by position papers on COPD published by the American Thoracic Society and the European Respiratory Society. ${ }^{33}$ The forced expiratory volume between $25 \%$ and $75 \%$ of the forced vital capacity $\left(\mathrm{FEF}_{25-75}\right)$ has been proposed to indicate mild airflow obstruction when the $\mathrm{FEV}_{1} / \mathrm{FVC}$ ratio is unchanged, especially in the follow-up of patients after lung transplantation (see below). However, the validity of $\mathrm{FEF}_{25-75}$ for detecting early mild airflow obstruction is not fully established.

Some patients with bronchiolitis obliterans who do not have a decreased $\mathrm{FEV}_{1} / \mathrm{FVC}$ ratio may have airway obstruction characterised by decreased $\mathrm{FVC}$ and $\mathrm{FEV}_{1}$ and increased residual volume (RV) and RV/total lung capacity (TLC); that is, a decrease in $\mathrm{FEV}_{1}$ provided TLC is normal may reflect airway obstruction. ${ }^{34-36}$ The potential limitations of body plethysmography for volume measurements in patients with bronchiolitis obliterans are less functionally important than those of the other techniques. ${ }^{37}$

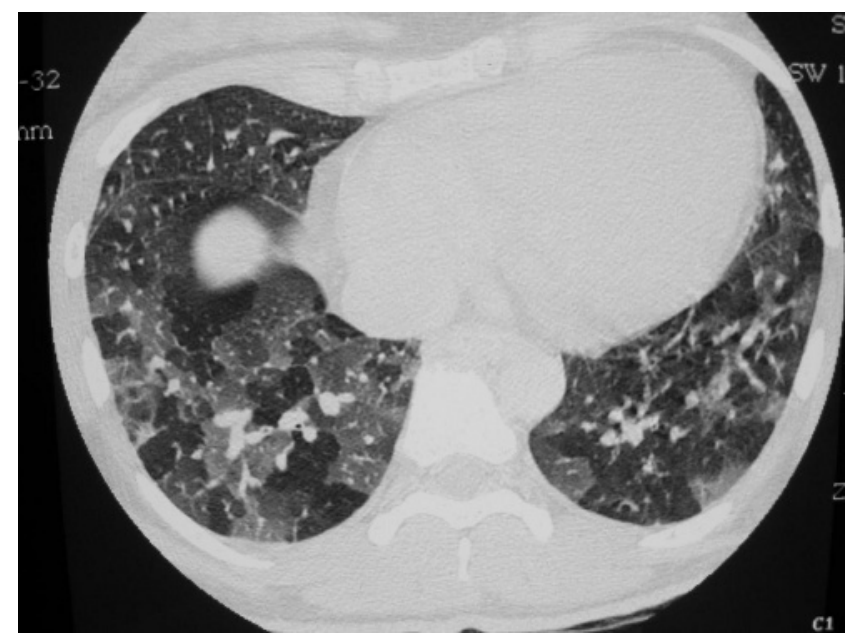

Figure 3 Characteristic mosaic pattern on expiratory high resolution CT scan showing association of areas of decreased and increased attenuation reflecting air trapping.

\section{Imaging findings}

The characteristic abnormalities reflecting obliterative bronchiolitis on HRCT scanning are well defined. Obliteration of the bronchioles which is not uniform results in indirect signs with areas of under-ventilated (air trapping) and consequently under-perfused (because of hypoxic vasoconstriction) lung alternating with normally ventilated and more perfused areas. These findings are more conspicuous at end-expiration, with respective decreased attenuation (black lung) and increased attenuation (grey lung) making up the characteristic mosaic pattern (fig 3). ${ }^{38-41}$ However, various degrees of air trapping (including the mosaic type) may be observed in subjects with normal pulmonary function without correlation with the subject's current smoking status or cigarette consumption. ${ }^{42}$ The HRCT finding of air trapping cannot therefore be considered as diagnostic for obliterative bronchiolitis in the absence of functional abnormalities. Bronchial dilation is often associated with this pattern as a result of diffuse longitudinal airway injury (enhanced by associated infection and possible hypogammaglobulinaemia)

Direct signs of bronchiolar disease may be present. Thickening of the bronchiolar wall by inflammatory cells results in centrilobular nodules; the tree-in-bud pattern is characterised by V- or Y-shaped branching linear opacities. Bronchiolectasis is identified by the presence of dilated bronchioles close to the pleural surface. These direct signs are usually absent at the stage of bronchiolar fibrosis.

The syndrome of obliterative bronchiolitis is not markedly different from COPD, with centrilobular emphysema in smokers resulting from chronic progressive destruction and ectasis of the bronchioles, and it also shares features with chronic asthma with airway wall remodelling. However, obliterative bronchiolitis differs from COPD and chronic asthma by its development usually within a few weeks or months.

\section{ALLOIMMUNE OBLITERATIVE BRONCHIOLITIS}

Obliterative bronchiolitis is a severe complication of both lung transplantation and HSC transplantation. Both conditions share clinical, imaging and lung function similarities. ${ }^{43}$ This is remarkable since, although the basic pathogenetic process is the same (an immune conflict between self and foreign cells), the agents of the conflict are exactly opposite: in lung transplantation the rejection process is operated by the recipient immune system against the transplanted lung, whereas after HSC transplantation the cells of the donor induce GVHD. Obliterative bronchiolitis is more common after lung transplantation than after HSC transplantation ( 50\% vs $10 \%)$.

\section{Lung transplantation}

Lung transplantation is the only treatment modality which improves the condition of patients with end-stage lung disease, especially COPD (which accounts for nearly half of all transplantations), idiopathic pulmonary fibrosis, cystic fibrosis and primary pulmonary hypertension. A smaller number of patients undergo transplantation for other indications such as sarcoidosis, Langerhans' cell granulomatosis (histiocytosis X) or lymphangioleiomyomatosis. Bilateral lung transplantation, lung transplantation and heart-lung transplantation are the three different possible procedures with age limits usually between 55 and 65 years.

In contrast to the reduction in early complications after lung transplantation, obliterative bronchiolitis remains the major cause of graft dysfunction and mortality after any type of lung transplantation. However, a reduced risk of obliterative bronchiolitis has been reported with double-lung transplantation compared with single-lung transplantation, a finding 
which needs to be confirmed given the possible consequences on the respective indications for these procedures. ${ }^{44} 45$

Five year survival after lung transplantation is about $50 \%$, in contrast to other organ transplantations where survival is usually more than $70 \%$. The prevalence of obliterative bronchiolitis in patients surviving at 5 years is about $50 \%$, with survival at 5 years after the onset of obliterative bronchiolitis being only $30-40 \%$. Obliterative bronchiolitis represents the leading cause of death after the first year following lung transplantation in both adults and children. ${ }^{46-49}$ The complex immune and non-immune mechanisms of obliterative bronchiolitis have been described in recent reviews and papers. ${ }^{47}$ 50-52

The many risk factors for obliterative bronchiolitis comprise probable, potential and hypothetical risk factors. ${ }^{53}{ }^{54}$ Probable risk factors include acute rejection episodes, lymphocytic bronchitis/bronchiolitis (non-infectious) and non-compliance with medication. Cytomegalovirus infection has been considered a significant risk factor, but a recent study ${ }^{55}$ did not find a significant difference in the development of obliterative bronchiolitis with any combination of donor/recipient serostatus for cytomegalovirus or histopathologically confirmed cytomegalovirus pneumonia treated with ganciclovir. Luckraz et $a l^{56}$ reported that the cytomegalovirus antibody status of the donor/recipient did not influence the incidence of obliterative bronchiolitis. Potential risk factors include organising pneumonia; viral (other than cytomegalovirus), ${ }^{57}$ bacterial and fungal infections; older donor age; longer graft ischaemic time; and donor antigen-specific reactivity. Hypothetical risks include underlying disease; human leucocyte antigen (HLA) mismatching; genotype of recipient; gastro-oesophageal reflux disease with early fundoplication resulting in a reduction in the incidence of obliterative bronchiolitis and longer survival; ${ }^{58}$ and ischaemia-reperfusion injury. ${ }^{59}$

Other risk factors have recently been reviewed. Obliterative bronchiolitis developed in $68 \%$ of patients with multiple minimal acute rejection at transbronchial lung biopsy (Al grade) compared with $43 \%$ of patients with $\leqslant 1$ Al lesion. ${ }^{60} \mathrm{~A}$ shorter obliterative bronchiolitis-free period has been reported for male donor and female recipient pairs. ${ }^{61}$ Chlamydia pneumoniae infection has been associated with obliterative bronchiolitis ${ }^{62}$ as well as high donor $C$ pneumoniae immunoglobulin $G$ (IgG) titres; ${ }^{63}$ in contrast, high recipient titres were inversely correlated with obliterative bronchiolitis. ${ }^{63}$ Nonimmune primary graft dysfunction due to acute lung injury with diffuse alveolar damage in early graft biopsy in patients surviving more than 30 days showed no significant difference in obliterative bronchiolitis-free time compared with recipients without early injury. ${ }^{64}$

The many reported risk factors above suggest that a number of these-both alloimmune and non-alloimmune (such as gastro-oesophageal reflux and infection)-may combine to

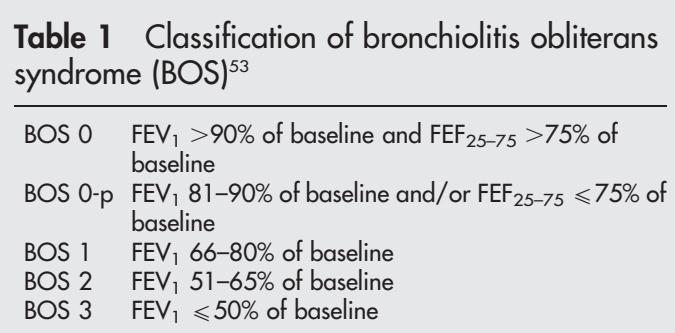

BOS 0-p, potential BOS stage; $\mathrm{FEF}_{25-75}$, mid expiratory flow rate; $\mathrm{FEV}_{1}$, forced expiratory volume in $1 \mathrm{~s}$. The mean of the two highest (not necessarily consecutive) measurements represents the baseline value with which the subsequent measurements are compared. induce or enhance the development of obliterative bronchiolitis. ${ }^{65}$

The median time between transplantation and the onset of obliterative bronchiolitis is 16-20 months. ${ }^{52}$ Compared with a slow linear decline in lung function, the onset of acute obliterative bronchiolitis has been associated with acute rejection in the first 6 months (often triggered by an acute event) and a poor prognosis. ${ }^{66}$ Patients with obliterative bronchiolitis developing $\geqslant 3$ years after single lung transplantation are less likely to develop troublesome functional impairment during long-term follow-up. ${ }^{67}$

The pathological diagnosis of bronchiolitis obliterans is difficult to obtain because the yield of transbronchial biopsy specimens is suboptimal and because of the invasiveness of surgical biopsy procedures. The International Society for Heart and Lung Transplantation therefore proposed a clinical definition for bronchiolitis obliterans syndrome (BOS) - graft deterioration with persistent airflow obstruction-based on pulmonary function tests updated to include the measurement of $\mathrm{FEF}_{25-75}$ and added a potential BOS stage (BOS 0-p) mainly defined by decreased $\mathrm{FEF}_{25-75}$ (table 1)..$^{53}$ However, the relevance of $\mathrm{FEV}_{1}$ and $\mathrm{FEF}_{25-75}$ to the definition of BOS 0-p is controversial. ${ }^{68-73}$

The role of systematic transbronchial biopsies in the followup after transplantation is not well established. Although limiting transbronchial biopsy procedures to patients with clinical indications probably does not compromise the detection rate for obliterative bronchiolitis, ${ }^{74}$ detecting occult rejection may help in modulating immunosuppressive or starting macrolide treatment. ${ }^{60}$ 75-80

Surrogate markers for detecting early obliterative bronchiolitis have been studied but not validated for use in clinical practice (bronchoalveolar lavage neutrophilia and increased cytokine levels; exhaled nitric oxide; air trapping on expiratory HRCT scan; bronchial hyperresponsiveness; changes in the distribution of ventilation).

The management of obliterative bronchiolitis is not established. Emphasis has been put on gastro-oesophageal reflux as a reversible cause of airflow obstruction after lung transplantation (which on its own increases the incidence of reflux probably because of several factors including vagus nerve dysfunction, effects of immunosuppressive medication on gastric emptying and dysfunction of the lower oesophageal sphincter). ${ }^{81}$ Gastro-oesophageal reflux might thus lead to obliterative bronchiolitis that is partly or completely reversible when treated..$^{53}$ As obliterative bronchiolitis is considered to be mainly a chronic rejection process, treatment consists of augmenting or modifying immunosuppression to improve or at least stabilise airflow obstruction. For example, conversion of cyclosporine to tacrolimus stabilised lung function in patients with obliterative bronchiolitis. ${ }^{82}{ }^{83}$ Azithromycin has been reported as a promising treatment for obliterative bronchiolitis, not only halting but reversing the deterioration in lung function. ${ }^{84-86}$ Pulmonary retransplantation is an option for patients with severe obliterative bronchiolitis, which is the main indication for retransplantation. ${ }^{87}$

Patients with obliterative bronchiolitis usually have associated bronchiectasis often colonised by Pseudomonas or Staphylococcus species, giving rise to chronic and acute infections which cause further deterioration in lung function. Hypogammaglobulinaemia, which is common after lung transplantation, is a further cause of infectious complications. ${ }^{88}$ IgG supplementation is probably indicated in such patients. All factors likely to be involved in the progression of obliterative bronchiolitis (such as gastro-oesophageal reflux) require adequate control. 


\section{Haematopoietic stem cell (HSC) transplantation}

GVHD occurs in $30-80 \%$ of HSC recipients and is mediated by dendritic cells, T cells, NK cells, macrophages, cytokines and surface markers on immune cells of the recipient. ${ }^{89-91}$ Acute GVHD occurring within the first weeks after transplantation does not significantly injure the lung (dermatitis, hepatitis, enteritis are the main manifestations). Chronic GVHD may be distinguished from acute GVHD by clinical symptoms including several features of connective tissue disease especially systemic sclerosis (although obliterative bronchiolitis is surprisingly absent in the latter). It occurs 80-100 days after the allograft in $30-60 \%$ of patients and is more common when HSC are used (instead of bone marrow) and when the donor is not an HLA identical sibling. The injury to the epithelia of the recipient by activated immune cells is a key process in GVHD. In chronic GVHD, serositis, hepatitis, gastrointestinal disease and bronchiolitis obliterans are characteristic manifestations. Autoantibodies to nuclear antigens similar to those associated with autoimmune diseases are commonly found. The dermal fibrosis in chronic GVHD resembles scleroderma.

The risk factors for obliterative bronchiolitis include chronic GVHD (of which obliterative bronchiolitis is further considered as a manifestation), peripheral blood stem cell transplantation, busulfan-based conditioning regimen, methotrexate, interval from diagnosis to transplantation $\geqslant 14$ months, female donor to transplant recipient sex match, prior interstitial pneumonia, increasing age at the time of transplantation, recipients with older donors, evidence of airflow obstruction before transplantation, respiratory viral infection and hypogammaglobulinaemia. ${ }^{92-98}$ Non-myeloablative stem cell transplantation may reduce the incidence of obliterative bronchiolitis. ${ }^{99} 100$

The estimated prevalence of obliterative bronchiolitis in allogeneic stem cell transplantation varies widely because of varying definitions, temporal changes in transplantation protocols and modalities of follow-up, but is estimated at about $9 \%$ with a range up to $48 \%{ }^{95}{ }^{101}$ An estimated incidence of $1.7 \%$ at 2 years was reported in adult patients with leukaemia who received HLA identical sibling HSC transplantation and survived at least 100 days after transplantation, as reported in the International Bone Marrow Transplantation Registry. ${ }^{92}$ Obliterative bronchiolitis occurs in up to one third of patients who develop chronic GVHD, ${ }^{94}$ and develops more than 100 days after transplantation (median 400-450 days). ${ }^{92} 95$

In contrast to patients undergoing systematically repeated lung function tests after lung transplantation, obliterative bronchiolitis is often discovered only in the presence of overt clinical manifestations at the stage of severe airflow obstruction. A comparison of lung function test results with those before transplantation is helpful for the early detection of airflow obstruction. The carbon monoxide transfer coefficient is normal. ${ }^{43}$

The course of obliterative bronchiolitis is variable, with some patients becoming stable while others develop a rapid decline in lung function. Infection in patients with bronchiectasis (especially when hypogammaglobulinaemia is present) is a further cause of progressive disease.

The significant attributable mortality rate of obliterative bronchiolitis in a recent series was $9 \%$ at 3 years after transplantation, $12 \%$ at 5 years after transplantation, and $18 \%$ at 10 years after transplantation, with higher rates for the subpopulation of patients with chronic GVHD (22\%, 27\% and $40 \%$, respectively). ${ }^{94}$ In another series, only $10 \%$ of patients with obliterative bronchiolitis survived at 5 years compared with $40 \%$ of those without obliterative bronchiolitis. ${ }^{95}$

As in obliterative bronchiolitis after lung transplantation, there is no established treatment but corticosteroids, immunosuppressants (cyclosporine, azathioprine), macrolides and control of factors suspected of contributing to the progression of obliterative bronchiolitis (such as infection, especially when hypogammaglobulinaemia is present) may be helpful. ${ }^{101}$ Extracorporeal photochemoradiotherapy has been reported to improve GVHD, including moderate/severe obliterative bronchiolitis (but patients with a very severe reduction in pulmonary function and those treated late do not respond to this treatment modality). ${ }^{102}$

\section{INFECTIVE OBLITERATIVE BRONCHIOLITIS}

Acute infective bronchiolitis is common in children, especially those aged $<1$ year. It is mainly of viral origin (especially respiratory syncytial virus) and the outcome is usually good. Other viruses (including parainfluenza viruses, adenoviruses, viruses of measles, mumps, varicella and influenza) or bacteria (especially Mycoplasma pneumoniae) are other causes of infective bronchiolitis. Obliterative bronchiolitis is a rare complication of acute infective bronchiolitis. Childhood bronchiolitis obliterans is characterised histologically by a constrictive pattern (and associated with large bronchi involvement with bronchiectasis ). ${ }^{103}$

\section{OBLITERATIVE BRONCHIOLITIS OF INHALATIONAL ORIGIN \\ Toxic gases and fumes}

Nitrogen dioxide and other gases, as well as fire fumes, are established causes of obliterative bronchiolitis. ${ }^{104-109}$ Obliterative bronchiolitis with pathological evidence of bronchiolitis obliterans and severe airflow obstruction has been reported in popcorn production plant workers exposed to volatile butterflavouring ingredients. ${ }^{10111}$

\section{Mineral and other dusts}

Mineral dust (including silica and asbestos) airway disease consists of fibrosis of the walls of the membranous and respiratory bronchioles and often pigmentation of the respiratory bronchioles associated with airflow obstruction. ${ }^{12-114}$ Associated centrilobular emphysema also probably contributes significantly to airflow obstruction.

Mixed dust fibrotic lesions are stellate-shaped lesions with varying degrees of collagenisation which have a tendency to spread diffusely into the adjacent lung tissue (diffuse interstitial fibrosis pattern). ${ }^{115}$

A patient engaged in the manufacture and repair of futons for 50 years developed a foreign body tissue reaction to cellulose fibres (a cotton dust pneumoconiosis different from byssinosis) with tiny granulomas and fibrous thickening of the peribronchiolar interstitium (with decreased indicators of small airways function). ${ }^{116}$

\section{Hypersensitivity pneumonitis}

Hypersensitivity pneumonitis caused by inhaled organic particles is characterised by lymphocytic inflammation of the bronchioles and the surrounding interstitial area. Many organic substances may induce this disorder, ${ }^{117}$ especially thermophilic actinomycetes contained in mouldy hay (farmer's lung) and bird droppings (bird breeder's disease). Clinical manifestations consist of acute or subacute symptoms with cough, dyspnoea and fever which develop a few hours after intense exposure to the antigen.

The chronic form of the disease may follow neglected and/or mild subacute manifestations, or develop insidiously leading to irreversible fibrotic interstitial lung disease. The acute stage of hypersensitivity pneumonitis is characterised by intense cellular inflammatory bronchiolitis with granulomatous interstitial inflammation near the terminal bronchioles, extending widely into the parenchyma. In contrast to sarcoidosis, the granulomas are loosely arranged and small ${ }^{118-120}$ and may even be lacking in 


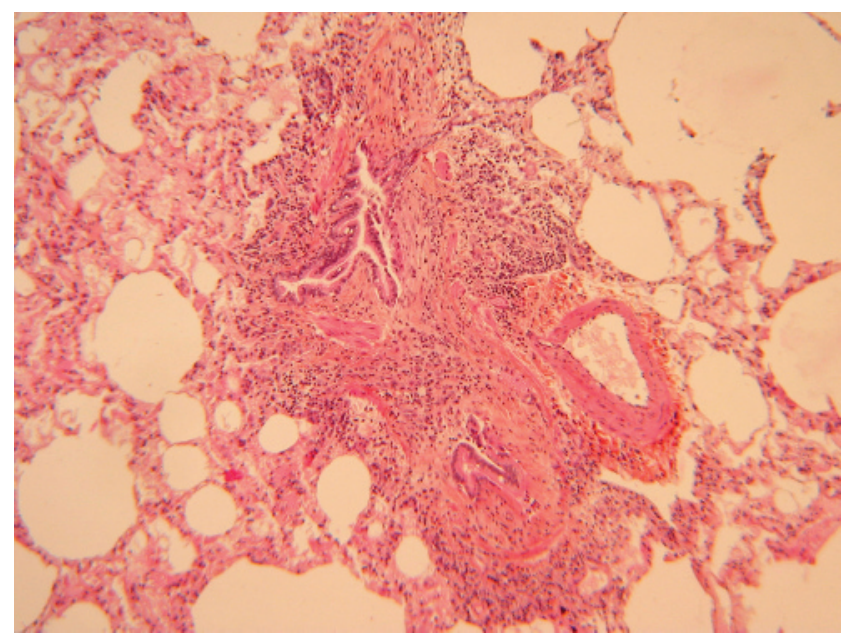

Figure 4 Constrictive fibrosing bronchiolitis preceding the clinical manifestations and diagnosis of rheumatoid arthritis.

some cases. ${ }^{121}$ Endoluminal proliferative bronchiolitis obliterans is present in about $25 \%$ of patients and organising pneumonia is also a common finding, , $^{119-121}$ so bronchiolitis obliterans with organising pneumonia is a characteristic feature of hypersensitivity pneumonitis.

Acute and subacute hypersensitivity pneumonitis usually improves with little if any sequelae provided the patient is not further exposed to the antigen (with or without associated short-term corticosteroid treatment). However, if the exposure persists, chronic fibrosing lesions may develop. These consist of diffuse interstitial fibrosis and focal peribronchial confluent areas of fibrosis sometimes with cystic changes; fibrosis predominates in the upper lobes. ${ }^{120}$ Even at the chronic stage, bronchiolar and peribronchiolar mononuclear cell inflammation persists and is associated with fibrosis in variable proportions. Whereas the acute form of hypersensitivity pneumonitis bronchiolitis is of the endoluminal proliferative type, it is constrictive in the chronic form. ${ }^{122}$ A pattern of irregular predominantly peribronchiolar fibrosis with associated peripheral fibrosis with architectural distortion and fibroblast foci resembling usual interstitial pneumonia has been reported. ${ }^{123}$ At the chronic stage the imaging pattern includes irregular linear opacities, honeycombing and traction bronchiectasis. ${ }^{124}$ The lower zone and peripheral predominance of these lesions is less common than in idiopathic pulmonary fibrosis ${ }^{125}$ where the lesions are predominantly in the middle lung zones. ${ }^{126}$ The occurrence of emphysema in addition to honeycombing has been emphasised. ${ }^{127}$ In the chronic stage of pigeon breeder's lung, the benefit of corticosteroids is not established and a mortality rate of $29 \%$ at 5 years has been reported. ${ }^{128}$ The presence of pathological fibrosis is predictive of increased mortality in patients with hypersensitivity pneumonitis. ${ }^{129}$

The participation of hypersensitivity reaction and genuine infection in Mycobacterium avium intracellulare bronchiolitis is controversial, especially in the so-called "hot tub lung". The infectious process is associated with the usual findings observed in mycobacterial infection. ${ }^{130}$ In patients with hypersensitivity, the clinical manifestations may be severe with respiratory failure. Airflow obstruction secondary to bronchiolitis is the dominant change in lung function with restriction and impaired diffusion in many patients. Peribronchiolar granulomas are usually well formed and may contain acid-fast bacilli, thus contrasting with the loose granulomas of classic hypersensitivity pneumonitis. Despite the intensity of the inflammation and in contrast to classic hypersensitivity pneumonitis, fibrosis does not develop and the outcome with antibiotics and/or corticosteroids is usually favourable without significant sequelae..$^{131-135}$

\section{OBLITERATIVE BRONCHIOLITIS IN CONNECTIVE TISSUE DISEASE}

Obliterative bronchiolitis with pathological evidence of bronchiolitis obliterans is mainly observed in the course of rheumatoid arthritis. ${ }^{136}$ Lymphoplasmacytic infiltrates, often peribronchiolar, are common in rheumatoid arthritis (with or without associated Sjögren syndrome), but some patients develop bronchiolitis obliterans with mucosal destruction and fibrosis of the bronchioles (often associated with the persistence of inflammatory cells). ${ }^{136-144}$

Obliterative bronchiolitis may develop before rheumatoid arthritis (fig 4) and may present with antinuclear antibodies and rheumatoid factor without any evidence of connective tissue disease. ${ }^{145} \mathrm{D}$-penicillamine may enhance the development of obliterative bronchiolitis in rheumatoid arthritis.

There is no established treatment for obliterative bronchiolitis in rheumatoid arthritis. Tumour necrosis factor (TNF) $\alpha$ has been reported to promote the development of obliterative bronchiolitis in a porcine bronchial model ${ }^{146}$ and in rat tracheal allografts $^{147}$ with improvement after TNF $\alpha$ inhibition. Improvement of refractory rheumatoid arthritis-associated constrictive bronchiolitis has been reported with etanercept, a soluble $\mathrm{TNF} \alpha$ receptor inhibitor. ${ }^{148}$

\section{OTHER CAUSES OF OBLITERATIVE BRONCHIOLITIS}

Bronchiolitis obliterans is a characteristic manifestation of paraneoplastic pemphigus, an autoimmune disorder characterised by IgG autoantibodies reacting against desmosomal and hemidesmosomal plakin proteins. Acantholysis, the loss of cellcell adhesion induced by autoantibodies, results in blistering of the stratified squamous epithelium of the skin and injury to the airway epithelium. ${ }^{149}$ The large airways are involved early in the course of the disease. Later involvement of the small airways results in bronchiolitis obliterans and severe respiratory failure leading to pulmonary transplantation or death. In a series of 28 patients with paraneoplastic pemphigus in association with Castleman's disease, 22 died from respiratory failure. ${ }^{150}$ The bronchiolar lesions comprise detachment of columnar epithelial cells, panmural infiltration of the bronchiolar walls almost exclusively by CD8+ T lymphocytes and replacement of the bronchiole by dense fibrosis occluding the lumen. ${ }^{149}{ }^{151-155}$ Castleman's disease and malignant lymphoma are the main causes of paraneoplastic pemphigus with bronchiolitis obliterans.

Drinking juice from the plant Sauropus androgynus, used to help weight control, resulted in an outbreak of obliterative bronchiolitis in Taiwan. ${ }^{156}$ The pathological findings consisted of focal fibromuscular sclerosis and obliteration of the bronchial arteries in the wall of the large bronchi with segmental necrosis of bronchi $2-4 \mathrm{~mm}$ in diameter ${ }^{157}$ and bronchiolar inflammation followed by bronchiolar fibrosis ${ }^{158} 159$ resulting in a constrictive obliterative bronchitis/bronchiolitis. ${ }^{158}$ The suspected agent was the alkaloid papaverine, and intratracheal administration of papaverine in a rat model did indeed induce bronchiolitis obliterans. ${ }^{160}$

Neuroendocrine cell tumourlets and idiopathic diffuse hyperplasia of pulmonary neuroendocrine cells most often involve the bronchioles. Associated bronchiolar fibrosis and scarring is usually present. Although tumourlets may develop on pre-existing chronic pulmonary lesions, the proliferation of neuroendocrine cells is probably the cause of airway wall fibrosis, possibly by the production of mediators (such as bombesin) capable of stimulating fibroblast growth and the 
production of collagen. ${ }^{161-167}$ When diffuse, both intraluminal obstruction by hyperplastic neuroendocrine cells and bronchiolar fibrosis result in irreversible airflow obstruction. ${ }^{161} 163$ 165-167

In Langerhans' cell granulomatosis ${ }^{168}$ the granulomas are systematically centred on the small airways, thus making the disease more like a bronchiolitis than an interstitial lung disease. ${ }^{169}$ The lesions extend down to the alveolar ducts, further progressing along the bronchiolar axis over time in both the proximal and distal directions. The cellular lesions evolve to cavitation and end-stage fibrosis and destruction of the bronchioles, ${ }^{169}$ and eventually to the development of the characteristic cysts seen on HRCT scanning. The fibrotic bronchioles may form characteristic stellate-shaped lesions. ${ }^{170}$

In bronchiolitis obliterans associated with organising pneumonia (BOOP) the air spaces of the whole lobule are filled with granulation tissue; the functional consequences are a restrictive ventilatory defect and the predominant imaging pattern is of patchy alveolar opacities (mainly consolidation). The intraluminal bronchiolar buds and those in the alveoli disappear with corticosteroid treatment, thus providing a model of reversible fibrosis. Organising pneumonia may be idiopathic or secondary to many causes or associated contexts (including lung and HSC transplantation and connective tissue disease). ${ }^{171}$

Although the main bronchiolar lesions in Wegener's granulomatosis are characterised by necrosis and granulomatous inflammation, BOOP is a common finding which may occasionally be prominent. Fibrotic scarring adjacent to necrosis is frequent. ${ }^{172-174}$

In sarcoidosis the granulomas, which are often located in the bronchial and bronchiolar submucosa, may compress and reduce the lumen of the bronchioles, especially when concentric fibrosis develops around them. ${ }^{175}$ Nevertheless, airflow obstruction often present in sarcoidosis has not been correlated with small airway involvement. ${ }^{176}{ }^{177}$ Perigranuloma fibrosis is typical in sarcoidosis but is rare in other granulomatous disorders with bronchiolitis such as hypersensitivity pneumonitis and hot tub lung. ${ }^{.78}$

Bronchiolitis obliterans is a common finding in patients with bronchiectasis of any cause including cystic fibrosis. ${ }^{175} 179180$ Peribronchiolar fibrosis has been reported in association with respiratory bronchiolitis in smokers. ${ }^{181-183}$ The contribution of airway wall remodelling and peribronchial fibrosis in COPD has not been established. ${ }^{184}$ Fibrosis of the bronchioles with peribronchiolar fibrosis has been reported at necropsy in patients with coeliac disease (including a patient with a remote history of bird fancier's lung, an association previously reported). ${ }^{185}$ Bronchiolitis obliterans has also been reported in

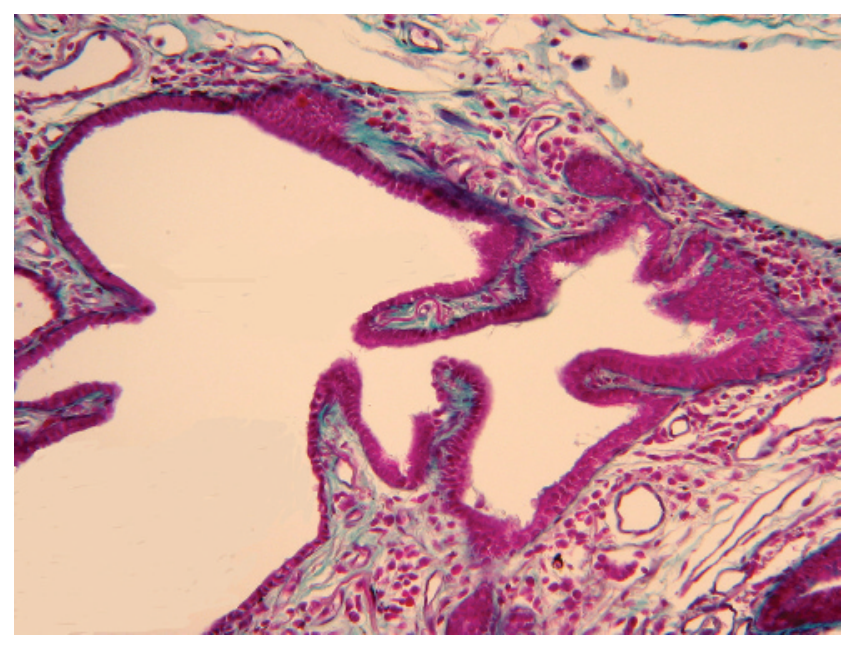

Figure 5 Bronchiolar epithelial metaplasia of the alveolar walls. other conditions such as ataxia-telangiectasia, ${ }^{186}$ inflammatory bowel disease, ${ }^{187}$ localised scleroderma treated with D-penicillamine $^{188}$ and psoriatic arthritis treated with gold therapy. ${ }^{189}$

\section{PERIBRONCHIOLAR METAPLASIA}

Peribronchiolar metaplasia is essentially a non-specific form of bronchiolar change $\mathrm{e}^{190}$ which occurs in many aetiological circumstances or as an idiopathic process. It consists of bronchiolar epithelial metaplasia usually associated with bronchiolar fibrosis extending to the peribronchiolar air spaces (fig 5), probably through the canals of Lambert (the condition is also known as lambertosis). Lambert described the eponymous accessory bronchiole-alveolar communications in cats, rabbits and humans and reported that these canals and their associated alveoli were early sites of dust-cell accumulation in coal miners. ${ }^{191}$ The canals interrupt the muscle bundles abruptly where they penetrate the walls of the terminal bronchioles. The epithelium lining generally corresponds to that of the bronchiole from which the tubule arises, ranging from tall columnar to low cuboidal or flattened cells with the lining usually continuing for some distance over the alveolar wall adjacent to the bronchiole. ${ }^{191}$ Epithelialisation of the air spaces in connection with fibrous-obliterated bronchioles has been reported by McLean in infective bronchiolitis, ${ }^{14}$ and this helps in the recognition of obliterated bronchioles (epithelialisation occurring both through bronchiolar-alveolar communications and in the air spaces where the scar terminates). The lining epithelium may become both hyperplastic and anaplastic, so distinction from atypical adenomatous hyperplasia and bronchioloalveolar carcinoma must be considered. ${ }^{190} 192$

Peribronchiolar metaplasia has been described in the idiopathic interstitial pneumonias in association with peribronchiolar fibrosis ${ }^{190} 193$ in up to $50-60 \%$ of cases with usual interstitial pneumonia, non-specific interstitial pneumonia or desquamative interstitial pneumonia. It has also been found in about half of all cases with hypersensitivity pneumonitis which is a characteristically bronchocentric cellular interstitial pneumonia. ${ }^{190}$

Peribronchiolar metaplasia of bronchiolar type epithelium was the only major histological finding recently reported in surgical lung biopsy specimens from patients (mainly older women) presenting with interstitial lung disease. ${ }^{190}$ Although some patients had associated connective tissue disease or a history of inhalation of agents capable of injuring the airways, in others the condition appeared to be idiopathic. In most patients, dyspnoea (usually mild) and cough were the main clinical manifestations, with mosaic and air trapping found at HRCT imaging and a restrictive pattern in lung function tests. Pathologically, the lesions consisted of fibrotically thickened bronchioles and peribronchiolar walls lined by an epithelium ranging from cuboidal to columnar and ciliated columnar cells without cellular atypia and generally without goblet cells; peribronchial fibrosis was most common, but the surrounding lung parenchyma was unremarkable. The clinical outcome was good; all patients survived with improvement in symptoms in some cases.

\section{IDIOPATHIC BRONCHIOLOCENTRIC INTERSTITIAL FIBROSIS}

A pathological pattern of bronchiolocentric inflammation and fibrosis with interstitial involvement has recently been reported under the names "idiopathic bronchiolocentric interstitial pneumonia", 194 "airway-centred interstitial fibrosis"195 and "centrilobular fibrosis". ${ }^{196}$ Patients presented with non-specific symptoms (cough and progressive dyspnoea), a restrictive pattern at lung function tests, and peribronchovascular interstitial thickening and traction bronchiectasis (and sometimes 
honeycombing or fibrotic masses) on HRCT scans. A history of possible exposure to inhalation agents was present in some cases. ${ }^{195}$ However, the clinical, imaging and lung function tests were not precisely detailed for most cases in the series. The common pathological finding was an airway-centred centrilobular disease with mural bronchiolar fibrosis and interstitial fibrosis extending from the airway, with prominent bronchiolar metaplasia in the fibrotic peribronchiolar air spaces.

Bronchiolitis with peribronchiolar organising pneumonia consists of bronchiolitis (inflammatory and fibrotic) associated with intra-alveolar buds of connective tissue limited to the alveoli adjacent to the involved bronchioles (with the buds occasionally forming casts of the canals of Lambert). ${ }^{197}$

\section{CRYPTOGENIC OBLITERATIVE BRONCHIOLITIS}

Obliterative bronchiolitis with bronchiolitis obliterans without any cause (especially smoking or asthma history) has been reported, predominantly in women. ${ }^{198-202}$ Whereas improvement may be obtained in some patients with corticosteroids with or without immunosuppressants, ${ }^{198}{ }^{201}$ others remain stable or progress to respiratory insufficiency. This type of obliterative bronchiolitis may be more common than is currently recognised, as an open lung biopsy specimen is seldom taken in patients with COPD of unknown cause.

\section{CONCLUSIONS}

Whatever its cause, fibrosing bronchiolitis results in irreversible airflow obstruction and further chronic respiratory failure in many patients. The peribronchiolar alveolar interstitium may be involved in the fibrotic process, with possibly prominent peribronchiolar metaplasia. Bronchiolocentric fibrosis is therefore a fibroproliferative disorder which is quite distinct from interstitial fibrosis, especially idiopathic pulmonary fibrosis.

\section{ACKNOWLEDGEMENTS}

The author thanks Lara Chalabreysse (Department of Pathology and Cytopathology, Louis Pradel University Hospital, Lyon, France) for providing histopathological figures and Timothy Greenland for linguistic supervision.

Competing interests: None.

\section{REFERENCES}

1 Reynaud AC. Mémoire sur l'oblitération des bronches. Mem Acad Med Paris 1835;4:117-67

2 Lange W. Ueber eine eigenthümliche Erkrankung der kleinen Bronchien und Bronchiolen. (Bronchitis et Bronchiolitis obliterans). Disch Arch Klin Med 1901;70:342-64.

3 Fraenkel A. Ueber Bronchiolitis fibrosa obliterans, nebst Bemerkungen über Lungenhyperämie une indurirende Pneumonie. Dtsch Arch Klin Med 1902:73:484-510.

4 Urbanski SJ, Kossakowska AE, Curtis J, et al. Idiopathic small airways pathology in patients with graft-versus-host disease following allogeneic bone marrow transplantation. Am J Surg Pathol 1987;11:965-71.

5 Yousem SA. The histological spectrum of pulmonary graft-versus-host disease in bone marrow transplant recipients. Hum Pathol 1995;26:668-75.

6 Myers JL, Colby TV. Bronchiolitis obliterans with organizing pneumonia and constrictive bronchiolitis: comparative analysis of two distinct entities. In: Fenoglio-Preiser CM, Wolff M, Rike F, eds. Progress in surgical pathology. New York: Springer Verlag, 1992:167-79.

7 Yousem SA. Small airways disease. Pathol Annu 1991;26:109-43.

8 Colby TV, Myers JL. Clinical and histologic spectrum of bronchiolitis obliterans including bronchiolitis obliterans organizing pneumonia. Semin Respir Med 1992;13:119-33.

9 Myers JL, Colby TV. Pathologic manifestations of bronchiolitis, constrictive bronchiolitis, cryptogenic organizing pneumonia, and diffuse panbronchiolitis. Clin Chest Med 1993;14:611-22.

10 Colby TV. Bronchiolitis. Pathologic considerations. Am J Clin Pathol 1998; 109: 101-9.

11 Couture C, Colby TV. Histopathology of bronchiolar disorders. Semin Respir Crit Care Med 2003;24:489-98.

12 Epler GR. The clinician's classification of the diseases of the bronchioles. In: Epler GR, eds. Diseases of the bronchioles. New York: Raven Press, 1994:101-12.
13 American Thoracic Society/European Respiratory Society. Classification of the idiopathic interstitial pneumonias. International multidisciplinary consensus. American Thoracic Society/European Respiratory Society. Am J Respir Crit Care Med 2002; 165:277-304.

14 McLean KH. The pathology of acute bronchiolitis: a study of its evolution. Part II: The repair phase. Australas Ann Med 1957;6:29-43.

15 McLean $\mathrm{KH}$. The pathology of acute bronchiolitis: a study of its evolution. Part I: The exudative phase. Australas Ann Med 1956;5:254-67.

16 Wright JL. Inhalational lung injury causing bronchiolitis. Clin Chest Med 1993; 14:635-44.

17 Horvath EP, doPico GA, Barbee RA, et al. Nitrogen dioxide-induced pulmonary disease. Five new cases and a review of the literature. J Occup Med 1978;20:103-10.

18 Lowry T, Schuman LM. "Silo-filler's disease": a syndrome caused by nitrogen dioxide. JAMA 1956;162:153-60.

19 McAdams AJ. Bronchiolitis obliterans. Am J Med 1955;19:314-22

20 Moskowitz RL, Lyons HA, Cottle HR. Silo filler's disease. Clinical, physiologic and pathologic study of a patient. Am J Med 1964;36:457-62.

21 Lenci G Wacker G, Schulz V, et al. Bronchiolitis obliterans nach Stickstoffdioxyd (NO2)-Inhalation: klinisch-röntgenologisch-histologische Beobachtung. Pneumologie 1990;44:32-6.

22 Arora NS, Aldrich TK. Bronchiolitis obliterans from a burning automobile. South Med J 1980;73:507-10.

23 Moran TJ, Hellstrom HR. Bronchiolitis obliterans. An experimental study of the pathogenesis and the use of cortisone in modification of the lesions. AMA Arch Pathol 1958;66:691-707.

24 Costa CLB, Spilborghs GMGT, Martins MA, et al. Nitric acid-induced bronchiolitis in rats mimics childhood bronchiolitis obliterans. Respiration 2005;72:642-9.

25 Beschorner WE, Saral R, Hutchins GM, et al. Lymphocytic bronchitis associated with graft-versus-host disease in recipients of bone marrow transplants. N Engl J Med 1978;299:1030-6.

26 Streichenberger N, Peyrol S, Philit F, et al. Constrictive bronchiolitis obliterans. Characterization of fibrogenesis and lysyl oxidase expression patterns. Virchows Arch 2001;439:78-84.

27 Cordier JF, Peyrol S, Loire R. Bronchiolitis obliterans organizing pneumonia as a model of inflammatory lung disease. In: Epler GR, eds. Diseases of the bronchioles. New York: Raven Press, 1994:313-45.

28 Basset $F$, Ferrans VJ, Soler $P$, et al. Intraluminal fibrosis in interstitial lung disorders. Am J Pathol 1986; 122:443-61.

29 Peyrol S, Cordier JF, Grimaud JA. Intra-alveolar fibrosis of idiopathic bronchiolitis obliterans-organizing pneumonia. Cell-matrix patterns. Am J Pathol 1990;137:155-70

30 Dunsmore SE, Shapiro SD. The bone marrow leaves its scar: new concepts in pulmonary fibrosis. J Clin Invest 2004;113:180-2.

31 Hashimoto $\mathbf{N}$, Jin $\mathrm{H}$, Liu $\mathrm{T}$, et al. Bone marrow-derived progenitor cells in pulmonary fibrosis. J Clin Invest 2004;113:243-52.

32 Bröcker V, Länger F, Fellous TG, et al. Fibroblasts of recipient origin contribute to bronchiolitis obliterans in human lung transplants. Am J Respir Crit Care Med 2006; 173:1276-82.

33 Celli BR, MacNee W. Standards for the diagnosis and treatment of patients with COPD: a summary of the ATS/ERS position paper. Eur Respir $J$ 2004;23:932-46.

34 Stanescu DC, Veriter C. A normal $\mathrm{FEV}_{1} / \mathrm{VC}$ ratio does not exclude airway obstruction. Respiration 2004:71:348-52.

35 Stanescu D. Small airways obstruction syndrome. Chest 1999;116:231-3.

36 Evans DJ, Green M. Small airways: a time to revisit? Thorax 1998;53:629-30.

37 Gruber MP, Nana-Sinkam SP, Chan ED. Airflow limitation and dynamic gas trapping in a bone marrow transplant recipient. Respir Care 2004;49:1542-5.

38 Ujita M, Hansell DM. Small-airways diseases: detection and insights with computed tomography. Eur Respir Mon 2004;30:106-44.

39 Hansell DM, Rubens MB, Padley SP, et al. Obliterative bronchiolitis: individual $\mathrm{CT}$ signs of small airways disease and functional correlation. Radiology 1997;203:721-6.

40 Stern EJ, Frank MS. Small-airway diseases of the lungs: findings at expiratory CT. AJR 1994;163:37-41

41 Pipavath SJ, Lynch DA, Cool C, et al. Radiologic and pathologic features of bronchiolitis. AJR 2005; 185:354-63.

42 Tanaka N, Matsumoto T, Miura G, et al. Air trapping at CT: high prevalence in asymptomatic subjects with normal pulmonary function. Radiology 2003;227:776-85.

43 Philit F, Wiesendanger T, Archimbaud E, et al. Post-transplant obstructive lung disease ("bronchiolitis obliterans"): a clinical comparative study of bone marrow and lung transplant patients. Eur Respir J 1995;8:551-8.

44 Levine SM. Lung transplantation and bronchiolitis obliterans syndrome: are two lungs better than one? Chest 2002;122:1112-4.

45 Hadjiliadis D, Davis RD, Palmer SM. Is transplant operation important in determining posttransplant risk of bronchiolitis obliterans syndrome in lung transplant recipients? Chest 2002;122:1168-75.

46 Meyers BF, de la Morena M, Sweet SC, et al. Primary graft dysfunction and other selected complications of lung transplantation: a single-center experience of 983 patients. J Thorac Cardiovasc Surg 2005; 129:1421-9.

47 Belperio JA, Lake K, Tazelaar H, et al. Bronchiolitis obliterans syndrome complicating lung or heart-lung transplantation. Semin Respir Crit Care Med 2003;24:499-530.

48 Trulock EP, Edwards LB, Taylor DO, et al. Registry of the International Society for Heart and Lung Transplantation: twenty-second official adult lung and heart lung transplant report-2005. J Heart Lung Transplant 2005;24:956-67. 
49 Boucek MM, Edwards LB, Keck BM, et al. Registry of the International Society for Heart and Lung Transplantation: eighth official pediatric report-2005. J Heart Lung Transplant 2005;24:968-82.

50 Neuringer IP, Chalermskulrat W, Aris R. Obliterative bronchiolitis or chronic lung allograft rejection: a basic science review. J Heart Lung Transplant 2005;24:3-19.

51 Belperio JA, Keane MP, Burdick MD, et al. Role of CXCR2/CXCR2 ligands in vascular remodeling during bronchiolitis obliterans syndrome. J Clin Invest 2005; 115:1150-62.

52 Boehler A, Estenne M. Post-transplant bronchiolitis obliterans. Eur Respir J 2003;22:1007-18.

53 Estenne M, Maurer JR, Boehler A, et al. Bronchiolitis obliterans syndrome 2001 an update of the diagnostic criteria. J Heart Lung Transplant 2002;21:297-310.

54 Sharples LD, McNeil K, Stewart S, et al. Risk factors for bronchiolitis obliterans: a systematic review of recent publications. J Heart Lung Transplant 2002;21:271-81.

55 Tamm M, Aboyoun CL, Chhajed PN, et al. Treated cytomegalovirus pneumonia is not associated with bronchiolitis obliterans syndrome. Am J Respir Crit Care Med 2004; 170:1120-3.

56 Luckraz H, Sharples L, McNeil K, et al. Cytomegalovirus antibody status of donor/recipient does not influence the incidence of bronchiolitis obliterans syndrome in lung transplantation. J Heart Lung Transplant 2003;22:287-91.

57 Khalifah AP, Hachem RR, Chakinala MM, et al. Respiratory viral infections are a distinct risk for bronchiolitis obliterans syndrome and death. Am J Respir Crit Care Med 2004;170:181-7.

58 Cantu III E, Appel JZ, Hartwig MG, et al. Early fundoplication prevents chronic allograft dysfunction in patients with gastroesophageal reflux disease. Ann Thorac Surg 2004;78:1142-51.

59 Fiser SM, Tribble CG, Long SM, et al. Ischemia-reperfusion injury after lung transplantation increases risk of late bronchiolitis obliterans syndrome. Ann Thorac Surg 2002;73:1041-8.

60 Hopkins PM, Aboyoun CL, Chhajed PN, et al. Association of minimal rejection in lung transplant recipients with obliterative bronchiolitis. Am J Respir Crit Care Med 2004; 170:1022-6

61 Roberts DH, Wain JC, Chang Y, et al. Donor-recipient gender mismatch in lung transplantation: impact on obliterative bronchiolitis and survival. J Heart Lung Transplant 2004;23:1252-9.

62 Glanville AR, Gencay M, Tamm M, et al. Chlamydia pneumoniae infection after lung transplantation. J Heart Lung Transplant 2005;24:131-6.

63 Kotsimbos TC, Snell GI, Levvey B, et al. Chlamydia pneumoniae serology in donors and recipients and the risk of bronchiolitis obliterans syndrome after lung transplantation. Transplantation 2005;79:269-75.

64 Fisher AJ, Wardle J, Dark JH, et al. Non-immune acute graft injury after lung transplantation and the risk of subsequent bronchiolitis obliterans syndrome (BOS). J Heart Lung Transplant 2002;21:1206-12.

65 Egan JJ. Obliterative bronchiolitis after lung transplantation: a repetitive multiple injury airway disease. Am J Respir Crit Care Med 2004;170:931-2.

66 Jackson CH, Sharples LD, McNeil K, et al. Acute and chronic onset of bronchiolitis obliterans syndrome (BOS): are they different entities? J Heart Lung Transplant 2002;21:658-6.

67 Brugiere O, Pessione F, Thabut G, et al. Bronchiolitis obliterans syndrome after single-lung transplantation: impact of time to onset on functional pattern and survival. Chest 2002;121:1883-9.

68 Nathan SD, Barnett SD, Wohlrab J, et al. Bronchiolitis obliterans syndrome: utility of the new guidelines in single lung transplant recipients. J Heart Lung Transplant 2003;22:427-32.

69 Hachem RR, Chakinala MM, Yusen RD, et al. The predictive value of bronchiolitis obliterans syndrome stage 0-p. Am J Respir Crit Care Med 2004; 169:468-72.

70 Lama VN, Murray S, Mumford JA, et al. Prognostic value of bronchiolitis obliterans syndrome stage $0-p$ in single-lung transplant recipients. Am J Respir Crit Care Med 2005;172:379-83.

71 Reynaud-Gaubert M, Thomas P, Badier M, et al. Early detection of airway involvement in obliterative bronchiolitis after lung transplantation. Functional and bronchoalveolar lavage cell findings. Am J Respir Crit Care Med 2000;161:1924-9

72 Patterson GM, Wilson S, Whang JL, et al. Physiologic definitions of obliterative bronchiolitis in heart-lung and double lung transplantation: a comparison of the forced expiratory flow between $25 \%$ and $75 \%$ of the forced vital capacity and forced expiratory volume in one second. J Heart Lung Transplant 1996;15:175-81.

73 Ouwens JP, van der Mark TW, Koeter GH, et al. Bronchiolar airflow impairment after lung transplantation: an early and common manifestation. $J$ Heart Lung Transplant 2002;21:1056-61.

74 Valentine VG, Taylor DE, Dhillon GS, et al. Success of lung transplantation without surveillance bronchoscopy. J Heart Lung Transplant 2002;21:319-26.

75 Aboyoun CL, Tamm M, Chhajed PN, et al. Diagnostic value of follow-up transbronchial lung biopsy after lung rejection. Am J Respir Crit Care Med $2001 ; 164: 460-3$.

76 Tamm M, Sharples LD, Higenbottam TW, et al. Bronchiolitis obliterans syndrome in heart-lung transplantation: surveillance biopsies. Am J Respir Crit Care Med 1997; 155:1705-10.

77 Yousem SA, Paradis I, Griffith BP. Can transbronchial biopsy aid in the diagnosis of bronchiolitis obliterans in lung transplant recipients? Transplantation 1994;57:151-3.

78 Day JD, Hutchins GM, Hruban RH. Grading pulmonary rejection: a proposal for a simplified system. J Heart Lung Transplant 1994;13:734-7.
79 Yousem SA, Berry GJ, Cagle PT, et al. Revision of the 1990 working formulation for the classification of pulmonary allograft rejection: Lung Rejection Study Group. J Heart Lung Transplant 1996;15:1-15.

80 Chakinala MM, Ritter J, Gage BF, et al. Yield of surveillance bronchoscopy for acute rejection and lymphocytic bronchitis/bronchiolitis after lung transplantation. J Heart Lung Transplant 2004;23:1396-404

81 Verleden GM, Dupont $U$, Van Raemdonck DE. Is it bronchiolitis obliterans syndrome or is it chronic rejection: a reappraisal? Eur Respir J 2005;25:221-4

82 Cairn J, Yek T, Banner NR, et al. Time-related changes in pulmonary function after conversion to tacrolimus in bronchiolitis obliterans syndrome. J Heart Lung Transplant 2003;22:50-7.

83 Sarahrudi $K$, Estenne $M$, Corris $P$, et al. International experience with conversion from cyclosporine to tacrolimus for acute and chronic lung allograft rejection. J Thorac Cardiovasc Surg 2004;127:1126-32.

84 Yates B, Murphy DM, Forrest IA, et al. Azithromycin reverses airflow obstruction in established bronchiolitis obliterans syndrome. Am J Respir Crit Care Med 2005; 172:772-5.

85 Gerhardt SG, McDyer JF, Girgis RE, et al. Maintenance azithromycin therapy for bronchiolitis obliterans syndrome. Am J Respir Crit Care Med 2003;168:121-5.

86 Verleden GM, Dupont $\amalg$. Azithromycin therapy for patients with bronchiolitis obliterans syndrome after lung transplantation. Transplantation 2004;77:1465-7

87 Novick RJ, Stitt LW, al-Kattan K, et al. Pulmonary retransplantation: predictors of graft function and survival in 230 patients. Ann Thorac Surg 1998;65:227-34

88 Kawut SM, Shah L, Wilt JS, et al. Risk factors and outcomes of hypogammaglobulinemia after lung transplantation. Transplantation 2005:79:1723-6.

89 Gilliam AC. Update on graft versus host disease. J Invest Dermatol 2004; 123:251-7.

90 Farag SS. Chronic graft-versus-host disease: where do we go from here? Bone Marrow Transplant 2004;33:569-77.

91 Watkins TR, Chien JW, Crawford SW. Graft versus host-associated pulmonary disease and other idiopathic pulmonary complications after hematopoietic stem cell transplant. Semin Respir Crit Care Med 2005;26:482-9.

92 Santo Tomas LH, Loberiza FR, Klein JP, et al. Risk factors for bronchiolitis obliterans in allogeneic hematopoietic stem-cell transplantation for leukemia. Chest 2005; 128:153-61

93 Ringden O, Remberger M, Ruutu T, et al. Increased risk of chronic graft-versushost disease, obstructive bronchiolitis, and alopecia with busulfan versus total body irradiation: long-term results of a randomized trial in allogeneic marrow recipients with leukemia. Blood 1999;93:2196-201.

94 Chien JW, Martin PJ, Gooley TA, et al. Airflow obstruction after myeloablative allogeneic hematopoietic stem cell transplantation. Am J Respir Crit Care Med 2003;168:208-14.

95 Dudek AZ, Mahaseth H, DeFor TE, et al. Bronchiolitis obliterans in chronic graftversus-host disease: analysis of risk factors and treatment outcomes. Biol Blood Marrow Tranplant 2003;9:657-66.

96 Holland HK, Wingard JR, Beschorner WE, et al. Bronchiolitis obliterans in bone marrow transplantation and its relationship to chronic graft-versus-host disease and low serum lgG. Blood 1988;72:621-7

97 Clark JG, Schwartz DA, Flournoy N, et al. Risk factors for airflow obstruction in recipients of bone marrow transplants. Ann Intern Med 1987; 107:648-56.

98 Clark JG, Crawford SW, Madtes DK, et al. Obstructive lung disease after allogeneic marrow transplantation. Clinical presentation and course. Ann Intern Med 1989;111:368-76.

99 Nusair S, Breuer R, Shapira MY, et al. Low incidence of pulmonary complications following nonmyeloablative stem cell transplantation. Eur Respir J 2004;23:440-5.

100 Yoshihara S, Tateishi U, Ando T, et al. Lower incidence of Bronchiolitis obliterans in allogeneic hematopoietic stem cell transplantation with reducedintensity conditioning compared with myeloablative conditioning. Bone Marrow Transplant 2005;35:1195-200.

101 Marras TK, Chan CK. Obliterative bronchiolitis complicating bone marrow transplantation. Semin Respir Crit Care Med 2003;24:531-41.

102 Dall'Amico R, Messina C. Extracorporeal photochemotherapy for the treatment of graft-versus-host disease. Therapeutic Apheresis 2002;6:296-304

103 Mauad T, Dolhnikoff M, the Sao Paulo Bronchiolitis Obliterans Study Group. Histology of chilhood bronchiolitis obliterans. Pediatr Pulmonol 2002;33:466-74.

104 Ghanei M, Mokhtari M, Mir Mohammad M, et al. Bronchiolitis obliterans following exposure to sulfur mustard: chest high resolution computed tomography. Eur J Radiol 2004;52:164-9.

105 Thomason JWW, Rice TW, Milstone AP. Bronchiolitis obliterans in a survivor of a chemical weapons attack. JAMA 2003;290:598-9.

106 Konichezky S, Schattner A, Ezri T, et al. Thionyl-chloride-induced lung injury and bronchiolitis obliterans. Chest 1993;104:971-3.

107 Cullinan P, Acquilla S, Dhara VR. Respiratory morbidity 10 years after the Union Carbide gas leak at Bhopal: a cross sectional survey. The International Medical Commission on Bhopal. BMJ 1997;314:338-42.

108 Zwemer FL, Pratt DS, May JJ. Silo filler's disease in New York State. Am Rev Respir Dis 1992;146:650-3.

109 Ramirez J, Dowell AR. Silo filler's disease:nitrogen dioxyde-induced lung injury. Long-term follow-up and review of the literature. Ann Intern Med 1971;74:569-76.

110 Akpinar-Elci M, Travis WD, Lynch DA, et al. Bronchiolitis obliterans syndrome in popcorn production plant workers. Eur Respir J 2004;24:298-302. 
111 Kreiss K, Gomaa A, Kullman G, et al. Clinical bronchiolitis obliterans in workers at a microwave-popcorn plant. N Engl J Med 2002;347:330-8.

112 Churg A, Wright JL, Wiggs B, et al. Small airways disease and mineral dust exposure. Prevalence, structure, and function. Am Rev Respir Dis 1985;131:139-43.

113 Churg A, Wright JL. Small-airway lesions in patients exposed to nonasbestos mineral dusts. Hum Pathol 1983;14:688-93.

114 Wright JL, Cagle P, Churg A, et al. Diseases of the small airways. Am Rev Respir Dis 1992;146:240-62.

115 Honma K, Abraham JL, Chiyotani K, et al. Proposed criteria for mixed-dust pneumoconiosis: definition, descriptions, and guidelines for pathologic diagnosis and clinical correlation. Hum Pathol 2004;35:1515-23.

116 Kobayashi H, Kanoh S, Motoyoshi K, et al. Diffuse lung disease caused by cotton fibre inhalation but distinct from byssinosis. Thorax 2004;59:1095-7.

117 Patel AM, Ryu JH, Reed CE. Hypersensitivity pneumonitis: current concepts and future questions. J Allergy Clin Immunol 2001;108:661-70.

118 Burke GW, Carrington CB, Strauss R, et al. Allergic alveolitis caused by home humidifiers. Unusual clinical features and electron microscopic findings. JAMA 1977;238:2705-8.

119 Reyes CN, Wenzel FJ, Lawton BR, et al. The pulmonary pathology of farmer's lung disease. Chest 1982;81:142-6.

120 Seal RM, Hapke EJ, Thomas GO, et al. The pathology of the acute and chronic stages of farmer's lung. Thorax 1968;23:469-89.

121 Emanuel DA, Wenzel FJ, Bowerman $\mathrm{Cl}$, et al. Clinical, pathologic and immunologic study of twenty-four patients. Am J Med 1964;37:392-401.

122 Perez-Padilla R, Gaxiola M, Salas J, et al. Bronchiolitis in chronic pigeon breeder's disease. Morphologic evidence of a spectrum of small airway lesions in hypersensitivity pneumonitis induced by avian antigens. Chest 1996; 110:371-7.

123 Churg A, Muller NL, Flint J, et al. Chronic hypersensitivity pneumonitis Am J Surg Pathol 2006;30:201-8.

124 Patel RA, Sellami D, Gotway MB, et al. Hypersensitivity pneumonitis: patterns on high-resolution CT. J Comput Assist Tomogr 2000;24:965-70.

125 Lynch DA, Newell JD, Logan PM, et al. Can CT distinguish hypersensitivity pneumonitis from idiopathic pulmonary fibrosis? AJR 1995; 165:807-11.

126 Adler BD, Padley SP, Muller NL, et al. Chronic hypersensitivity pneumonitis: high-resolution CT and radiographic features in 16 patients. Radiology 1992; 185:91-5.

127 Remy-Jardin M, Remy J, Wallaert B, et al. Subacute and chronic bird breeder hypersensitivity pneumonitis: sequential evaluation with $\mathrm{CT}$ and correlation with lung function tests and bronchoalveolar lavage. Radiology 1993;189:111-8.

128 Perez-Padilla R, Salas J, Chapela R, et al. Mortality in Mexican patients with chronic pigeon breeder's lung compared with those with usual interstitial pneumonia. Am Rev Respir Dis 1993;148:49-53.

129 Vourlekis JS, Schwarz MI, Cherniack RM, et al. The effect of pulmonary fibrosis on survival in patients with hypersensitivity pneumonitis. Am J Med 2004; 116:662-8.

130 Fujita J, Ohtsuki Y, Suemitsu I, et al. Pathological and radiological changes in resected lung specimens in Mycobacterium avium intracellulare complex disease. Eur Respir J 1999;13:535-40.

131 Marras TK, Wallace RJ Jr, Koth LL, et al. Hypersensitivity pneumonitis reaction to Mycobacterium avium in household water. Chest 2005; 127:664-71

132 Anon. Case records of the Massachusetts General Hospital. Case 9-2005. N Engl J Med 2005;352:1238-46.

133 Field SK, Fisher D, Cowie RL. Mycobacterium avium complex pulmonary disease in patients without HIV infection. Chest 2004;126:566-81

134 Anon. Case records of the Massachusetts General Hospital. Case 27-2000. N Engl J Med 2000;343:642-9.

135 Anon. Case records of the Massachusetts General Hospital. Case 6-1996. N Engl J Med 1996;334:521-6.

136 Hakala M, Paakko P, Sutinen S, et al. Association of bronchiolitis with connective tissue disorders. Ann Rheum Dis 1986:45:656-62.

137 Begin R, Masse S, Cantin A, et al. Airway disease in a subset of nonsmoking rheumatoid patients. Characterization of the disease and evidence for an autoimmune pathogenesis. Am J Med 1982;72:743-50.

138 Geddes DM, Corrin B, Brewerton DA, et al. Progressive airway obliteration in adults and its association with rheumatoid disease. Q J Med 1977;46:427-44.

139 Pegg SJ, Lang BA, Mikhail EL, et al. Fatal bronchiolitis obliterans in a patient with juvenile rheumatoid arthritis receiving chrysotherapy. J Rheumatol 1994;21:549-51

140 Yam LY, Wong R. Bronchiolitis obliterans and rheumatoid arthritis. Report of a case in a Chinese patient on $d$-penicillamine and review of the literature. Ann Acad Med Singapore 1993;22:365-8.

141 Penny WJ, Knight RK, Rees AM, et al. Obliterative bronchiolitis in rheumatoid arthritis. Ann Rheum Dis 1982:41:469-72.

142 Murphy KC, Atkins CJ, Offer RC, et al. Obliterative bronchiolitis in two rheumatoid arthritis patients treated with penicillamine. Arthritis Rheum 1981;24:557-60

143 Epler GR, Snider GL, Gaensler EA, et al. Bronchiolitis and bronchitis in connective tissue disease. A possible relationship to the use of penicillamine. JAMA 1979;242:528-32

144 Jansen HM, Elema JD, Hylkema BS, et al. Progressive obliterative bronchiolitis in a patient with rheumatoid arthritis. Eur J Respir Dis 1982;63(Suppl):43-52.

145 Jacobs $\mathbf{P}$, Bonnyns M, Depierreux M, et al. Rapidly fatal bronchiolitis obliterans with circulating antinuclear and rheumatoid factors. Eur J Respir Dis 1984:65:384-8.

146 Alho HS, Maasilta PK, Harjula AL, et al. Tumor necrosis factor-alpha in a porcine bronchial model of obliterative bronchiolitis. Transplantation 2003;76:516-23.
147 Farivar AS, Mackinnon-Patterson B, McCourtie AS, et al. Obliterative airway disease in rat tracheal allografts requires tumor necrosis factor alpha. Exp Mol Pathol 2005;78:190-7.

148 Cortot AB, Cottin V, Miossec P, et al. Improvement of refractory rheumatoid athritis-associated constrictive bronchiolitis with etanercept. Respir Med 2005:99:511-14.

149 Nousari HC, Deterding R, Wojtczack H, et al. The mechanism of respiratory failure in paraneoplastic pemphigus. N Engl J Med 1999;340:1406-10.

150 Nikolskaia OV, Nousari CH, Anhalt GJ. Paraneoplastic pemphigus in association with Castleman's disease. Br J Dermatol 2003;149:1143-51

151 Chin AC, Stich D, White FV, et al. Paraneoplastic pemphigus and bronchiolitis obliterans associated with a mediastinal mass: a rare case of Castleman's disease with respiratory failure requiring lung transplantation. J Pediatr Surg 2001;36:E22

152 Gudi VS, Ormerod AD, Weir J, et al. Severe breathlessness, mouth ulcers and skin blistering in a female. Eur Respir J 2004;24:884-7.

153 Hoffman MA, Qiao X, Anhalt GJ. CD8+ lymphocytes in bronchiolitis obliterans paraneoplastic pemphigus, and solitary Castleman's disease. N Engl J Med 2003:349:407-8.

154 Hasegawa Y, Shimokata K, Ichiyama S, et al. Constrictive bronchiolitis obliterans and paraneoplastic pemphigus. Eur Respir J 1999;13:934-7.

155 Takahashi M, Shimatsu Y, Kazama T, et al. Paraneoplastic pemphigus associated with bronchiolitis obliterans. Chest 2000;117:603-7.

156 Lai RS, Chiang AA, Wu MT, et al. Outbreak of bronchiolitis obliterans associated with consumption of Sauropus androgynus in Taiwan. Lancet 1996;348:83-5

157 Chang YL, Yao YT, Wang NS, et al. Segmental necrosis of small bronchi after prolonged intakes of Sauropus androgynus in Taiwan. Am J Respir Crit Care Med 1998;157:594-8.

158 Wang JS, Tseng HH, Lai RS, et al. Sauropus androgynus-constrictive obliterative bronchitis/bronchiolitis: histopathological study of pneumonectomy and biopsy specimens with emphasis on the inflammatory process and disease progression. Histopathology 2000;37:402-10

159 Chang H, Wang JS, Tseng HH, et al. Histopathological study of Sauropus androgynus-associated constrictive bronchiolitis obliterans: a new cause of constrictive bronchiolitis obliterans. Am J Surg Pathol 1997:21:35-42.

160 Svetlecic J, Molteni A, Herndon B. Bronchiolitis obliterans induced by intratracheal papaverine: a novel animal model. Lung 2004;182:119-34.

161 Aguayo SM, Miller YE, Waldron JA Jr, et al. Idiopathic diffuse hyperplasia of pulmonary neuroendocrine cells and airways disease. $N$ Engl J Med 1992;327:1285-8

162 Ranchod $M$. The histogenesis and development of pulmonary tumorlets. Cancer 1977;39:1135-45.

163 Miller RR, Muller NL. Neuroendocrine cell hyperplasia and obliterative bronchiolitis in patients with peripheral carcinoid tumors. Am J Surg Pathol 1995; 19:653-8.

164 Bennett GL, Chew FS. Pulmonary carcinoid tumorlets. AJR 1994;162:568.

165 Brown MJ, English J, Muller NL. Bronchiolitis obliterans due to neuroendocrine hyperplasia: high-resolution CT-pathologic correlation. AJR 1997; 168:1561-2.

166 Lee JS, Brown KK, Cool C, et al. Diffuse pulmonary neuroendocrine cell hyperplasia: radiologic and clinical features. J Comput Assist Tomogr 2002;26:180-4.

167 Sheerin N, Harrison NK, Sheppard MN, et al. Obliterative bronchiolitis caused by multiple tumourlets and microcarcinoids successfully treated by single lung transplantation. Thorax 1995;50:207-9.

168 Tazi A, Soler P, Hance AJ. Adult pulmonary Langerhans' cell histiocytosis. Thorax 2000:55:405-16.

169 Kambouchner M, Basset F, Marchal J, et al. Three-dimensional characterization of pathologic lesions in pulmonary Langerhans' cell histiocytosis. Am J Respir Crit Care Med 2002;166:1483-90.

170 Friedman P, Liebow AA, Sokoloff J. Eosinophilic granuloma of lung. Clinical aspects of primary pulmonary histiocytosis in the adult. Medicine (Baltimore) 1981;60:385-96.

171 Cordier JF. Organising pneumonia. Thorax 2000;55:318-28.

172 Travis WD, Hoffman GS, Leavitt RY, et al. Surgical pathology of the lung in Wegener's granulomatosis. Review of 87 open lung biopsies from 67 patients. Am J Surg Pathol 1991;15:315-33.

173 Uner AH, Rozum-Slota B, Katzenstein AL. Bronchiolitis obliterans-organizing pneumonia (BOOP)-like variant of Wegener's granulomatosis. A clinicopathologic study of 16 cases. Am J Surg Pathol 1996;20:794-801.

174 Mark EJ, Matsubara O, Tan-Liu NS, et al. The pulmonary biopsy in the early diagnosis of Wegener's (pathergic) granulomatosis: a study based on 35 open lung biopsies. Hum Pathol 1988;19:1065-71.

175 Travis WD, Colby TV, Koss MN, et al. Non-neoplastic disorders of the lower respiratory tract. Washington, DC: American Registry of Pathology and Armed Forces Institute of Pathology, 2002

176 Hansell DM, Milne DG, Wilsher ML, et al. Pulmonary sarcoidosis: morphologic associations of airflow obstruction at thin-section CT. Radiology 1998;209:697-704.

177 Lavergne F, Clerici C, Sadoun D, et al. Airway obstruction in bronchial sarcoidosis: outcome with treatment. Chest 1999;116:1194-9.

178 Cheung OY, Muhm JR, Helmers RA, et al. Surgical pathology of granulomatous interstitial pneumonia. Ann Diagn Pathol 2003;7:127-38.

179 Culiner MM. Obliterative bronchitis and bronchiolitis with bronchiectasis. Dis Chest 1963;44:351-61.

180 Sobonya RE, Taussig LM. Quantitative aspects of lung pathology in cystic fibrosis. Am Rev Respir Dis 1986;134:290-5. 
181 Fraig M, Shreesha U, Savici D, et al. Respiratory bronchiolitis: a clinicopathologic study in current smokers, ex-smokers, and never-smokers. Am J Surg Pathol 2002;26:647-53.

182 Anon. Case records of the Massachusetts General Hospital. Case 11-1998. N Engl J Med 1998;338:1051-8.

183 Cottin V, Streichenberger N, Gamondes JP et al. Respiratory bronchiolitis in smokers with spontaneous pneumothorax. Eur Respir J 1998;12:702-4.

184 Chung KF. The role of airway smooth muscle in the pathogenesis of airway wall remodeling in chronic obstructive pulmonary disease. Proc Am Thorac Soc 2005;2:347-54

185 Edwards C, Williams AJ, Asquith P. Bronchopulmonary disease in coeliac patients. J Clin Pathol 1985;38:361-7.

186 Ito M, Nakagawa A, Hirabayashi N, et al. Bronchiolitis obliterans in ataxiatelangiectasia. Virchows Arch 1997;430:131-7.

187 Camus P, Piard F, Ashcroft T, et al. The lung in inflammatory bowel disease. Medicine (Baltimore) 1993;72:151-83.

188 Boehler A, Vogt P, Speich R, et al. Bronchiolitis obliterans in a patient with localized scleroderma treated with D-penicillamine. Eur Respir $J$ 1996;9:1317-9.

189 Schwartzman KJ, Bowie DM, Yeadon C, et al. Constrictive bronchiolitis obliterans following gold therapy for psoriatic arthritis. Eur Respir J 1995;8:2191-3.

190 Fukuoka J, Franks TJ, Colby TV, et al. Peribronchiolar metaplasia: a common histologic lesion in diffuse lung disease and a rare cause of interstitial lung disease: clinicopathologic features of 15 cases. Am J Surg Pathol 2005;29:948-54.
191 Lambert MW. Accessory bronchiole-alveolar communications. J Pathol Bacteriol 1955;70:311-4.

192 Brandt HM, Liebow AA. Acinar type of atypical proliferation in the lung in relation to the canals of Lambert. Am J Pathol 1957;33:582.

193 Chilosi M, Murer B, Doglioni C, et al. Bronchiolar epithelium in idiopathic pulmonary fibrosis/usual interstitial fibrosis. In: Lynch JP, eds. Idiopathic pulmonary fibrosis. New York: Marcel Dekker, 2004:631-64.

194 Yousem SA, Dacic S. Idiopathic bronchiolocentric interstitial pneumonia. Mod Pathol 2002;15:1148-53.

195 Churg A, Wright JL. Bronchiolitis caused by occupational and ambient atmospheric particles. Semin Respir Crit Care Med 2003;24:577-83.

196 Carvalho CR, Bethlem EP. Pulmonary complications of leptospirosis. Clin Chest Med 2002;23:469-78.

197 Thivolet F, Loire R, Cordier JF. Bronchiolitis with peribronchiolar organizing pneumonia (B-POP): a new clinicopathologic entity in bronchiolar/interstitial ung disease? Eur Respir J 1999;14(Suppl 30):272s.

198 Markopoulou KD, Cool CD, Elliott TL, et al. Obliterative bronchiolitis: varying presentations and clinicopathological correlation. Eur Respir J 2002;19:20-30.

199 Kraft M, Mortenson RL, Colby TV, et al. Cryptogenic constrictive bronchiolitis. A clinicopathologic study. Am Rev Respir Dis 1993;148:1093-101.

200 Turton CW, Williams G, Green M. Cryptogenic obliterative bronchiolitis in adults. Thorax 1981;36:805-10.

201 Hawley PC, Whitcomb ME. Bronchiolitis fibrosa obliterans in adults. Arch Intern Med 1981;141:1324-7.

202 Noble MI, Fox B, Horsfield K, et al. Obliterative bronchiolitis with atypical features: CT scan and necropsy findings. Eur Respir J 1993;6:1221-5.

\section{LUNG ALERT}

\section{Risk factors associated with superspreading events in SARS}

$\Delta$ Yu IT, Xie ZH, Tsoi KK. Why did outbreaks of severe acute respiratory syndrome occur in some hospital wards but not in others? Clin Infect Dis 2007:44:1017-25.

$\mathrm{T}$ he severe acute respiratory syndrome (SARS) outbreak of 2003 originated in Hong Kong, China, and $71.1 \%$ of the subsequent infections in Hong Kong were attributable to superspreading events. Most of these superspreading events occurred in hospitals.

This case control study identified risk factors associated with outbreaks of SARS in hospital wards in Guangzhou and Hong Kong, China. Case wards were wards in which superspreading events occurred and control wards were wards in which patients with SARS were admitted, but no superspreading events occurred. A superspreading event was defined as the development of $\geqslant 3$ new cases of SARS in the 2-10-day period after the admission of an identifiable index patient, or the development of a cluster of $\geqslant 3$ new cases of SARS in an 8-day period, when there was no known index case.

Results were collected from 86 wards (40.7\% case wards) in 21 hospitals in Guangzhou and 38 wards $(34.2 \%$ case wards) in 5 hospitals in Hong Kong. The main environmental and administrative factors associated with the occurrence of superspreading events were:

- a minimum distance between beds of $\leqslant 1 \mathrm{~m}$,

- lack of washing or changing facilities for staff

- staff working while experiencing symptoms

- workload of $>2$ patients per healthcare worker.

Significant host factors associated with superspreading events included the use of oxygen therapy, a nebuliser and/or bi-level positive airway pressure ventilation.

This study identifies a number of factors associated with the occurrence of superspreading events. Although confined to two cities in southern China, with the threat of avian flu worldwide other countries may benefit from adopting some of these infection control measures to help to minimise outbreaks of respiratory infection.

Ali A Mohammed Specialist Registrar in Respiratory Medicine, Royal infirmary in Edinburgh; alimohammed@doctors.org.uk 